\title{
Integrating Career Development Techniques Into The Business School Curriculum: Tools For Better Preparing Our Graduates For Successful Careers
}

\author{
Randall S. Hansen, (E-mail: rhansen@stetson.edu), Stetson University
}

\begin{abstract}
With shortening semesters, longer textbooks, and new information and business techniques being published, business school faculty face a constant pressure to find the time to teach all the "hard skills" our disciplines require. At the same time, our graduates need certain career development skills to succeed. This paper proposes an inventory of career development techniques, the Career Development Inventory (CDI), that business school faculty could incorporate into their classes to help students develop, evaluate, and achieve their career goals. These exercises have time requirements that range from 10 minutes of class time to projects completed by the students outside of class, thus offering business school faculty a wide range of options.
\end{abstract}

\section{Introduction}

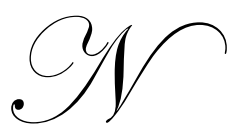

umerous articles have been published in both the popular press and in academic journals and proceedings about the importance of college graduates - and specifically business school graduates having the key career development tools to not only obtain their first job upon graduation, but also to succeed on the job. One of the key findings Collins (1998) reports is that recent college graduates cite uncertainty about exactly what they want to do as an obstacle to a successful job search. Other research has shown that recent graduates have a poor grasp on their own skills and abilities, on critical job-search skills, and on strategies for career advancement (Brousseau and Driver 1994), as well as unrealistic career expectations and a lack of a career focus (Sheetz 1995).

Indeed, Lyon and Kirby (2000) go as far as to state: "In addition to helping students develop their intellectual skills, professors and universities must also provide guidance and assistance regarding career options, the nature of professional work, resume building, interviewing, and other job-hunting skills" (p. 276). The authors conclude with: "it is important to bring exercises into the classroom that are designed to develop student career attainment skills" (p. 276). Gault, Redington, and Schlager (2000) state: "A critical but often overlooked area of higher education is the career success of graduating seniors" (p. 52).

Employers also have been vocal about the essential skills college graduates need to succeed on the job, and several studies list career development as essential (Carnevale, Gainer, and Meltzer 1990; Holter and Kopka 2001). Several articles have been published in academic journals and proceedings detailing classroom techniques and exercises designed to improve career development and workplace skills (cf Davis and Miller 1996; Gault, Redington, and Schlager; Goldgehn 1989; Hafer and Hoth 1981; Hansen 1998; Kaman and Kretovics 1999; Kramer 1988; Lyon and Kirby 2000)

Readers with comments or questions are encouraged to contact the author via email.

It seems only logical that business faculty and business students are the best match for career-development exercises because of the many parallels between good business skills and career-development and job-hunting skills. 
Finally, yet another reason to add more career-development exercises into the classroom comes from Buhler (2001), who states that all employees must now be responsible for their own career development. Students who pick up these key self-awareness and career-development skills while in college can use these tools for the rest of their lives.

\section{Overview of the Career Development Inventory}

The Career Development Inventory (CDI) was developed after examining all the best career-development practices that have been discussed in previous journals and academic conferences. It consists of three levels of career-development activities, with each level requiring a different time commitment inside or outside of class by the student, and different levels of commitment from the faculty member.

The three levels of the CDI are defined as:

- Briefs. These are exercises designed to take no more than 10 minutes of class time, with little or no burden on the faculty member. Some of these exercises can be spontaneous, while others require a previous assignment so students can research the topic. All require some element of written or verbal communication.

- $\quad$ Fulls. These are exercises designed for most or all of a class period, with many requiring the faculty member to spend time prior to the class booking guest speakers or prepping new material. Many also have optional homework assignments.

- $\quad$ Externals. These are exercises designed for students to complete outside of class time. No class time is committed to these exercises, but most are designed for some type of class discussion or student presentation, and most require extra time by the faculty member for grading.

\section{Exhibit 1 shows the complete Career Development Inventory}

One of the main concerns that arises from faculty - besides the use of valuable class time - is how these exercises will be graded. The answer is that these exercises can be graded in just about any manner the faculty member chooses, from including the exercises as part of a participation grade (especially the Briefs) to fully graded projects/papers (especially the Externals). The question of how to grade these exercises should not be a hindrance to their use in the classroom.

Finally, many of the exercises in the CDI use the key skills employers are looking for in business school graduates, such as oral presentations/communications, written communications, computer applications, and analytical skills (Floyd and Gordon 1998; Karakaya and Karakaya 1996; Kelley and Gaedeke 1990).

\section{The CDI Exercises: Briefs}

These career exercises are designed to take minimal class time - up to 10 minutes. These are great exercises for either regularly scheduled in-class assignments or during days when extra time remains.

"On the Spot" Interview Questions. Professors obtain a list of the commonly asked interview questions (available on many career Websites and in many job-hunting books) and randomly asks a specific student to answer one of the questions, as if on a job interview. After the student answers the question, use the remaining time for class discussion regarding the strengths and weaknesses of the response. This exercise can be repeated numerous times throughout a semester - or at the start or close of every class.

List Your Potential Network. Students often assume they have a very limited network of people to help them with job-hunting. This exercise is designed to have students brainstorm a list of people (family members, neighbors, family friends, classmates, etc.) who could be in their career and job-hunting network. Professors can take this assignment to the next level by asking several people to share their lists so that other students can further brainstorm outside of class about others to include in their networks. 
1-Minute Networking. Students have one minute to introduce themselves to a classmate and brainstorm how they can help each other achieve their career goals. This exercise can be repeated numerous times throughout a semester - or at the start or close of every class.

Career Snapshots. All business majors offer multiple career paths - which often require different skill sets and different preparation. Specific career paths can be assigned for students to research and present, or the professor can lead the discussion about them. These snapshots could be a regular assignment throughout the semester.

Career Quizzes (marketability, interviewing, cover letter, etc.). Multiple sources - in print and on the Web offer short (up to 20 questions) quizzes that students can take that relate to a variety of job-hunting skills. After completing and scoring the results, students can discuss the results as a whole or break into smaller groups to share experiences.

Self-Assessment. Numerous self-assessment tests are available on and off the Web. While some of these tests are quite long (making a good External exercise), others are shorter. This exercise could also be used in combination with the SWOT Analysis. Students should be told that the results of these tests are meant only as a basis of deeper reflection on themselves and their career goals.

SWOT Analysis. Even though students conduct numerous SWOT analyses on various organizations and companies, most rarely take the time to conduct a SWOT analysis on themselves. Professors may want to separate the four elements for shorter timeframes, or to allow students to research the external opportunities and threats outside of class time. This exercise is a great tool for students to focus on their strengths and weaknesses - in terms of career development - and could include having students develop a plan for reducing or eliminating their weaknesses.

Transferable Skills Scenarios. This exercise works well in small groups or with the entire class, and is great for helping students realize all jobs provide them with critical skills that are transferable (Hansen, K. 1998). A description of a typical college student's work experience is displayed and students are asked to identify the key transferable skills from that experience than can be applied to a specific type of job upon graduation, such as business consultant.

Unique Selling Proposition (USP). The USP is an advertising term that is easily applied to job-seekers. It is that one thing that distinguishes a product (or job-seeker) from all other similar brands (or job-seekers). Students, especially after completing the SWOT Analysis, should be able to identify their USP, or the USP they want to have by the time they graduate.

Resume/Cover Letter Critiques. The professor distributes copies of a resume or cover letter to the class and instructs students to spend five minutes finding errors or problems - and strategies for improving them. The last five minutes are spent with the resume or cover letter on an overhead projector, with class discussion based on individual critiques.

Job-Hunting Etiquette. So often it is the little things that separate job-seekers; thus, this assignment could actually be a series of discussions or exercises about specific types of job-hunting etiquette: phone etiquette, email etiquette, interviewing etiquette, business dining etiquette, and follow-up etiquette. Students could critique and discuss various etiquette scenarios or discuss various “do's and don'ts" rules of job - hunting.

Shared Experiences. Often a favorite of the students, this exercise has a particular student (or students) share their on-the-job experiences from previous jobs and internships, as well as networking and interviewing experiences. This assignment is loosely structured, but students could discuss issues such as corporate culture, working conditions, technology, morale, benefits, salary, interview questions, etc. Assuming most students, especially in upper-division business courses, have had one or more work experiences, this assignment could be a regularly scheduled assignment throughout the semester.

Researching Companies. Having knowledge of targeted companies is a critical factor in job-hunting. Have 
each student pick one company to conduct research on and report back to the class in a short presentation. This assignment is fairly unstructured, but should include things such as company size, divisions, financial performance, hiring practices, corporate culture, etc.

\section{The CDI Exercises: Fulls}

These career exercises take most, if not all, of a class period. Of all the career development exercises, these are obviously the hardest to fit into a full semester of coursework.

Self-Assessment. As mentioned in the Briefs section, numerous self-assessment tests are available on and off the Web. While some of these tests are quite long (making a good External exercise), others are shorter. This exercise could also be used in combination with the SWOT Analysis. Students should be told that the results of these tests are meant only as a basis of deeper reflection on themselves and their career goals. Small group discussions based on the results - could follow.

Cover Letter/Resume Workshop. If the professor is comfortable about the subject, he/she can lead this workshop; if not, he/she can request a counselor from their college's career services office to lead the workshop. Students leave this exercise with a clearer understanding of the value and importance of these job correspondence tools. This exercise can also result in the assignment of one or more of the Externals listed below.

Resume/Cover Letter Critiques. The professor breaks the class into groups and distributes different copies of a resume or cover letter to each group, along with an overhead transparency of the document. Groups then spend time discussing and critiquing their assigned document, with each group presenting and discussing their results toward the end of class.

Job-Hunting on the Internet Workshop. The instructor takes students through various career development and job-hunting Websites, with discussions about strengths and weaknesses of using the Internet for job-hunting. This exercise can either be done in the classroom, or more interactively in a computer lab setting where students follow along in the workshop. Here's one example: http://www.quintcareers.com/student_jobseeker_guide/.

Guest Speakers. Many business classes have guest speakers, but as proposed here, guest speakers would be used not only to discuss a specific content-related issue, but also about jobs and careers in their company and their industry, as well as how to break into that career. This exercise could also be turned into a networking opportunity for students by leaving time at the end of class for informal discussions with the speaker, or providing a separate time outside of class.

Employer Decision Model. Borrowing from the consumer decision-making model, this exercise takes students through the job-placement process from the employer's point of view. Key benefits of this exercise for students include understanding the process employers go through - and why many jobs are never advertised. More details of this assignment can be found at: http://www.quintcareers.com/career_journal/five.html.

Mock Interviewing. This assignment can be a full or an external, depending on whether the instructor wants to be part of the interviewing process. Students are assigned to find a job listing that matches the type of job they would like to interview for when graduating. Students are assigned to prepare for the interview, perhaps using the external interview question assignment. Students are then interviewed by a panel that may include the instructor and/or a counselor from the career services office, several classmates, and a guest professional. Performance feedback is provided to each student.

Website Resume Workshop. Placing student resumes and portfolios on the Web, allowing 24/7 access by potential employers, is a growing trend. Instructors or guest speakers from the college's information technology department can conduct a one-class workshop on the basics of Web publishing and converting existing documents into Web documents. 
Shared Experiences. If not used as a Brief, the shared experiences can instead be converted into a one day or more - workshop where students discuss their work experiences from internships and previous jobs. This assignment is loosely structured, but students could discuss issues such as corporate culture, working conditions, technology, morale, benefits, salary, etc.

\section{The CDI Exercises: Externals}

These career exercises take place outside the classroom, although the results of the exercises can be used as starting points for career discussions in the classroom.

Cover Letters. Students are assigned to write a cover letter to a real employer or a response to a real job posting, for either a job or internship. Students should include a copy of the job posting or an explanation of the purpose of the cover letter.

Resumes. Students are assigned to write one or more drafts of their resume - or polish an existing resume. Students can also be assigned to register their resume with the career services office on campus or one or more college graduate-oriented job Websites.

Website. As mentioned in the Fulls section, placing student resumes and portfolios on the Web, allowing $24 / 7$ access by potential employers, is a growing trend. Either in conjunction with an information technology class or with the aid of the university's information technology group, students can be assigned to develop a basic Website, with resume (and possible career portfolio).

Career Snapshots. As mentioned in the Briefs section, all business majors offer multiple career paths which often require different skill sets and different preparation. Specific career paths can be assigned for students to research. Students could submit written reports and/or present their results as part of an in-class discussion of careers.

Self-Assessment. As mentioned in the Briefs section, numerous self-assessment tests are available on and off the Web. This exercise could also be used in combination with many of the other exercises. Students should be told that the results of these tests are meant only as a basis of deeper reflection on themselves and their career goals. Students are required to take several of these tests and then write a short paper discussing the results.

Mission Statements. Many business classes discuss the value of a corporate mission statement to the success of the firm. In this exercise, students can apply the principles of corporate mission statements to themselves to develop a personal mission statement. This assignment can also be used as a way for students to better understand and relate to each other by having students read their mission statements in class, though professors should make this part optional as some students may choose not to read theirs in class. More on crafting personal mission statements can be found in this article:

http://www.quintcareers.com/mission_statements.html.

Career Portfolio. It used to be that portfolios were just for creative careers, but as more business schools require larger individual and team projects, most students graduate with multiple papers that demonstrate some of the key skills employers seek, such as problem-solving, writing, and analytical skills (Floyd and Gordon 1998; Karakaya and Karakaya 1996; Kelley and Gaedeke 1990). Students can be assigned to develop a print or electronic version of their career portfolio. More information can be found at http://www.quintcareers.com/job_search_portfolio.html.

Career Journal. As described by Hansen (1998), "is more than a tool about helping marketing students; it is a tool to help all students (regardless of their major) attending a basic marketing class to apply the concepts of marketing to themselves and thus better understand the concepts of marketing while becoming better prepared and more knowledgeable about their chosen career field. It is designed to help students become more aware of career paths, career goals, and career and job-hunting strategies" (p. 152). The Website for this assignment can be found at: 
http://www.quintcareers.com/career_journal/.

Career Planning Essay. As described by Lyon and Kirby (2000), students are assigned to "write an essay that helps them develop and evaluate their career goals; reflect on the interrelationship between personal values, career goals, and lifestyle goals; and develop an action plan to achieve their goals" (p. 276). Students answer three questions in their essay: (1) Where do I want to be? (2) Where am I now?; and (3) How am I going to get there?

Autobiography. Students are assigned to write their personal life story, focusing on four main areas: education, activities, work history, and family. Students then should analyze how these four areas will affect their future choices, and then develop some plans for changing one or more of these areas to help them achieve their overall career goals and objectives.

Etiquette Dinners. Many college career services offices and sometimes business student organizations sponsor some kind of etiquette dinner or event. Students can be required to attend the event and write a short paper explaining what they learned.

Interview Questions/Answers. Either in combination with the "On the Spot" Interview Questions assignment mentioned in the Briefs section or as a separate assignment, students are assigned a list of the most common interview questions and are assigned to develop (and write) answers for each question. This assignment could also be used in combination with the Mock Interviewing exercise.

SWOT Analysis. As mentioned in the Briefs section, even though students conduct numerous SWOT analyses on various organizations and companies, most rarely take the time to conduct a SWOT analysis on themselves. This exercise is a great tool for students to focus on their strengths and weaknesses - in terms of career development and could include having students develop a plan for reducing or eliminating their weaknesses.

Informational Interviews. Students are assigned to complete a certain number of informational interviews with managers and executives in their projected career fields. As defined by Bolles (1990) and further refined by Hansen (2000), an informational interview is the process of engaging a network contact in a "highly focused conversation" that provides key information about a particular career. Hansen reports numerous benefits from informational interviews, from more knowledge about a career to offers of internships and jobs.

Researching Companies. Many business classes require students to conduct some form of company or industry research, but anecdotal information shows that students really only know a limited number of sources for this kind of information. This assignment focuses on broadening their sources of information, as well as taking a different spin on research by having students research companies from a job-hunting perspective. Students can be assigned one or more companies to research and be used in combination as a Brief exercise.

Mock Interviewing. This assignment can be a full or an external, depending on whether the instructor wants to be part of the interviewing process. Students are assigned to find a job listing that matches the type of job they would like to interview for when graduating. Students are assigned to prepare for the interview, perhaps using the external interview question assignment. Students are then interviewed by a panel that may include the instructor and/or a counselor from the career services office, several classmates, and a guest professional. Performance feedback is provided to each student.

Field Trips. Often thought of as an activity for primary education, field trips to manufacturing facilities, distribution centers, advertising agencies, and corporate offices can all lead to a better understanding of various business processes - and could be incorporated into a networking opportunity for students.

Internships. The value of one or more internships to business graduates is significant. Gault, Redington, and Schlager (2000) report significant early career advantages for undergraduates with internship experience, including less time to find their first job, increased salary levels, and great job satisfaction. According to the American Council on Education, 9 out of 10 four-year colleges now offer some sort of structured work experience (internships 
and co-ops) related to a student's major or career interest (Tooley 1997). Hite and Bellizzi (1986) state that internships provided a more valuable learning experience than case courses or listening to a series of guest lectures in class. Besides the work experience, students could be required to keep a journal (Aim 1996) and/or present their experiences.

\section{Discussion and Conclusion}

All of the exercises in the CDI are designed to help students better understand possible career choices as well as be better prepared for job-hunting and the beginning of their careers upon graduation. Other outcomes of these exercises include helping students discover new majors and minors, or helping them find a new career direction if they determine their current choice is no longer one they want to pursue.

Time is always a factor in teaching business courses, but the value of the CDI is that it offers professors a wide variety of choices in terms of exercises and amount of class time consumed. Other factors that need to be taken into consideration include the amount and type of grading the professor wishes to do and the type and size of class.

Even with the limitations and other considerations professors face, serious consideration should be given to incorporating one or more of the CDI exercises into existing business classes.

\section{References}

1. Aim, C. T. (1996), "Using Student Journals to Improve the Academic Quality of Internships.” Journal of Education for Business, Nov./Dec., 113-115.

2. Bolles, R. N. (1990), What Color is Your Parachute? Berkeley, CA: Ten Speed Press.

3. Brousseau, K. R. and M. Driver (1994), "Enhancing Informed Choice: A Career Concepts Approach to Career Advisement," Selections, 10, 24-31.

4. Buhler, P. M. (2001), "The Growing Importance of Soft Skills in the Workplace," Supervision, 62 (6), 13+.

5. Carnevale, A. P., L. J. Gainer, and A. S. Meltzer (1990), Workplace Basics: The Essential Skills Employers Want. San Francisco: Jossey-Bass.

6. Collins, M. (1998), "Great Expectations: What Students have to say About the Process and Practice of Launching a Career," Journal of Career Planning and Placement, Spring, 41-47.

7. Davis, B. D. and T. R. Miller (1996), "Job Preparation for the $21^{\text {st }}$ Century: A Project Learning Model to Teach Basic Workplace Skills," Journal of Education for Business, 72 (2), 69-73.

8. Floyd, C. J. and M. E. Gordon (1998), "What Skills are Most Important? A Comparison of Employer, Student, and Staff Perceptions," Journal of Marketing Education, 20 (Summer), 103-09.

9. Gault, Jack, John Redington, and Tammy Schlager (2000), "Undergraduate Business Internships and Career Success: Are They Related?" Journal of Marketing Education, 22 (1), 45-53.

10. Goldgehn, L. A. (1989), "Student Placement: The Challenge of Helping Our Undergraduate Marketing Students Prepare for the Job Marketplace and Their Careers in Marketing," Journal of Marketing Education, Fall, 78-82.

11. Hafer, J. C. and C. C. Hoth (1981), "Grooming Your Marketing Students to Match the Employer's Ideal Job Candidate," Journal of Marketing Education, Spring, 15-19.

12. Hansen, K. S. (2000), A Foot in the Door: Networking Your Way into the Hidden Job Market. Berkeley, CA: Ten Speed Press.

13. Hansen, K. S. (1998), Dynamic Cover Letters for New Graduates. Berkeley, CA: Ten Speed Press.

14. Hansen, R. S. (1998), "Combining Marketing Principles with Career Preparedness in a Principles of Marketing Class: The Marketing Career Journal," Proceedings of the $14^{\text {th }}$ Annual Atlantic Marketing Association, vol. 14, 151-158.

15. Hite, Robert and Joseph Bellizzi (1986), "Student Expectations Regarding Collegiate Internship Programs in Marketing," Journal of Marketing Education, 8 (Fall), 41-49.

16. Holter, N. C. and D. C. Kopka (2001), “Developing a Workplace Skills Course: Lessons Learned, ” Journal of Education for Business, 76 (3), 138-143.

17. Kaman, V. S. and M. A. Kretovics (1999), "Experience and Career Focus: A Framework for Advising and 
Placing Business Interns,” Journal of Career Planning \& Employment, 59 (2), 32-35+.

18. Karakaya, Fahri and Fera Karakaya (1996), “Employer Expectations from a Business Education,” Journal of Marketing for Higher Education, 7 (1), 9-16.

19. Kelley, C. A. and R. M. Gaedeke (1990), "Student and Employer Evaluation of Hiring Criteria for EntryLevel Marketing Positions," Journal of Marketing Education, 12 (Fall), 64-71.

20. Kramer, H. E. (1988), "Applying Marketing Strategy and Personal Value Analysis to Career Planning: An Experiential Approach," Journal of Marketing Education, Fall, 69-73.

21. Lyon, D. W. and E. G. Kirby (2000), “The Career Planning Essay,” Journal of Management Education, 24 (2), 276-287.

22. Sheetz, L. P. (1995), Recruiting Trends 1995-96. East Lansing, MI: Michigan State University Collegiate Employment Research Institute.

23. Tooley, JoAnn (1997), "Working for Credit: How to Make the Most out of a Semester-Long Internship," U.S. News \& World Report, Nov. 17, 76-78.

\section{Recommended Career Books} lege library.

Here's a collection of career books that instructors could list as references - or place on reserve in the col-

- $\quad$ College Grad Job Hunter, by Brian Krueger. Adams Media Corp.

- $\quad$ The Complete Resume \& Job Search For College Students, by Bob Adams with Laura Morin. Adams Media Corp.

- $\quad$ Dynamic Cover Letters for New Graduates, by Katharine Hansen. Ten Speed Press. A Foot in the Door, by Katharine Hansen. Ten Speed Press.

- $\quad$ Killer Interviews, by Frederick W. Ball and Barbara B. Ball. McGraw-Hill. Resumes for College Students and Graduates. VGM Career Horizons.

\section{Recommended Career Websites}

Here's a collection of career Websites that can be used as a reference for both instructors and students.

- College Grad Job Hunter. A great Website based on the book. URL: http://www.collegegrad.com/.

- CollegeJournal, from the publishers of the Wall Street Journal. URL: http://www.collegejournal.com/.

- $\quad$ CollegeRecruiter.com. An internship and employment site. URL: http://www.collegerecruiter.com.

- $\quad$ EmployU.com: jobs, internships, and career advice. URL: http://www.employu.com/.

- Jobweb: Career Course Syllabi. A collection of syllabi with career exercises. URL:

- $\quad$ http://www.jobweb.com/catapult/course/content.htm.

- Quintessential Careers: The College, Careers, and Job Guide. URL: http://www.quintcareers.com.

- WetFeet.com offers information on numerous industries and careers. URL: http://wetfeet.com/.

\section{Exhibit 1: Career Development Inventory}

I. Briefs

- “On the Spot” Interview Questions

- $\quad$ List Your Potential Network

- $\quad$ 1-Minute Networking

- $\quad$ Career Snapshots

- $\quad$ Career Quizzes (marketability, interviewing, cover letter, etc.)

- $\quad$ Self-Assessment 


\section{- $\quad$ SWOT Analysis}

- $\quad$ Transferable Skills Scenarios

- Unique Selling Proposition (USP)

- Resume/Cover Letter Critiques

- Job-Hunting Etiquette

- $\quad$ Shared Experiences

- $\quad$ Researching Companies

II. Fulls

- $\quad$ Self-Assessment

- $\quad$ Cover letter/Resume Workshop

- Resume/Cover Letter Critiques

- Job-Hunting on the Internet Workshop

- Guest Speakers

- $\quad$ Employer Decision Model

- $\quad$ Mock Interviewing

- $\quad$ Website Resume Workshop

- $\quad$ Shared Experiences

III. Externals

$\begin{array}{ll}\text { - } & \text { Cover Letter(s) } \\ \text { - } & \text { Resume(s) } \\ \text { - } & \text { Website } \\ \text { - } & \text { Career Snapshots } \\ \text { - } & \text { Mission Statements } \\ \text { - } & \text { Career Portfolio } \\ \text { - } & \text { Career Journal } \\ \text { - } & \text { Career Planning Essay } \\ \text { - } & \text { Autobiography } \\ \text { - } & \text { Etiquette Dinners } \\ \text { - } & \text { Interview Questions/Answers } \\ \text { - } & \text { SWOT Analysis } \\ \text { - } & \text { Informational Interviews } \\ \text { - } & \text { Researching Companies } \\ \text { - } & \text { Mock Interviewing } \\ \text { - } & \text { Field Trips } \\ \text { - } & \text { Internships }\end{array}$

Notes 